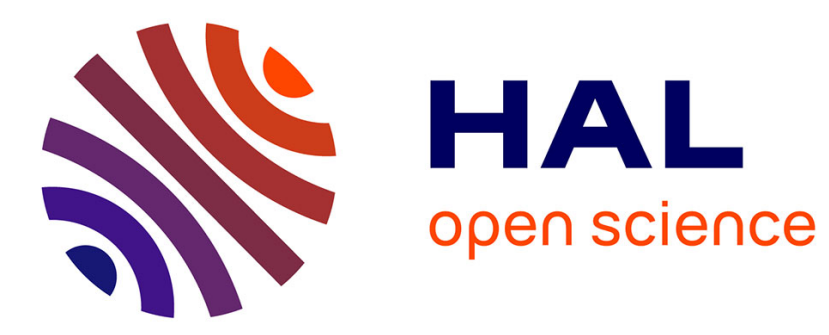

\title{
Net radiation model evaluation at an hourly time step for mediterranean conditions
}

\author{
Samuel Ortega-Farias, Rodrigo Antonioletti, Albert Olioso
}

\section{To cite this version:}

Samuel Ortega-Farias, Rodrigo Antonioletti, Albert Olioso. Net radiation model evaluation at an hourly time step for mediterranean conditions. Agronomie, 2000, 20 (2), pp.157-164. 10.1051/agro:2000116 . hal-00886002

\section{HAL Id: hal-00886002 https://hal.science/hal-00886002}

Submitted on 1 Jan 2000

HAL is a multi-disciplinary open access archive for the deposit and dissemination of scientific research documents, whether they are published or not. The documents may come from teaching and research institutions in France or abroad, or from public or private research centers.
L'archive ouverte pluridisciplinaire HAL, est destinée au dépôt et à la diffusion de documents scientifiques de niveau recherche, publiés ou non, émanant des établissements d'enseignement et de recherche français ou étrangers, des laboratoires publics ou privés. 


\title{
Net radiation model evaluation at an hourly time step for mediterranean conditions ${ }^{1}$
}

\author{
Samuel ORTEGA-FARIAS ${ }^{\mathrm{a}}$, Rodrigo ANTONIOLETTI ${ }^{\mathrm{b} *}$, Albert OliOso $^{\mathrm{b}}$ \\ ${ }^{a}$ Servicio Integrado de Agroclimatoligía y Riego (SIAR), Departamento de Producción Agrícola, Facultad de Ciencia Agrarias, \\ Universidad de Talca, Casilla 747, Talca, Chili \\ b INRA, Unité de Bioclimatologie, Domaine St. Paul, 84914 Avignon Cedex 9, France
}

(Received 11 May 1999; revised 18 November 1999; accepted 14 December 1999)

\begin{abstract}
A study was performed to evaluate a model for computing net radiation over grass canopies located in Talca (Chile) and Avignon (France). In both locations, an automatic meteorological station was installed over a grass maintained in reference conditions to measure net radiation, solar radiation, air temperature and air vapour pressure on a hourly basis. Results indicated that there was a good correlation between measured (Rno) and estimated (Rne) values of net radiation, with a correlation coefficient greater than 0.95 for both locations. Major disagreements were observed during the night time, but they did not affect the final calculation of net radiation. This analysis suggest that the model could be used in the Penman-Monteith equation to compute crop water requirement in Avignon and Talca, using network measurements for the evaluation of net radiation.
\end{abstract}

\section{Net radiation / effective atmospheric emissivity}

Résumé - Évaluation d'un modèle de rayonnement net à base horaire en conditions méditerranéennes. Un modèle de calcul du rayonnement net sur gazon a été évalué dans des conditions de référence à Talca (Chili) et à Avignon (France). Des stations automatiques ont été utilisées pour mesurer sur une base horaire le rayonnement net, le rayonnement solaire global, la température et l'humidité de l'air. Les résultats obtenus montrent une bonne corrélation entre les estimations (Rne) et les mesures (Rno) de rayonnement net. Les résultats obtenus avec ce modèle sont assez probants pour l'utiliser dans l'équation actualisée de Penman-Monteith. L'intérêt de cette démarche est qu'elle permet d'utiliser des mesures de réseau pour évaluer le rayonnement net.

rayonnement net / émissivité atmosphérique

Communicated by Gérard Guyot (Avignon, France)

${ }^{1}$ Action réalisée dans le cadre du programme ECOS de coopération entre la France et le Chili, № C99U04.

* Correspondence and reprints

rodrigo@avignon.inra.fr 


\section{Introduction}

Technological advances have made it possible to develop automated meteorological sensors and stations which perform measurements at a time step equal or lower than one hour, are easy to use, and have a reasonable cost. Thus, the way is now open to calculate crop water requirements with a physical and physiological basis, for instance with the Penman-Monteith model [1, 3, 15, 23, 24]. However, some components of the energy balance such as the net radiation are still difficult to measure. They have to be estimated from easier measurements such as incident solar radiation, air temperature, and air humidity, using physical and/or statistical relationships $[3,4,15,16,18,22]$.

A study was performed to evaluate a model for estimating net radiation at an hourly time step from classical meteorological data. This model was designed for the calculation of crop water requirements. Then, it was only tested in so-called "reference conditions" which consider an "extensive surface of 8 to $15 \mathrm{~cm}$ tall, green grass cover of uniform height, actively growing, completely shading the ground and not short of water [11]. Two datasets, from Avignon in the South of France and Talca in the Middle Chile, were used.

\section{Theoretical background}

The net radiation corresponds to the surface radiative balance in the solar domain $(0.15 \mu \mathrm{m}$ to 4 $\mathrm{mm})$ and the thermal domain ( $3 \mu \mathrm{m}$ to $100 \mu \mathrm{m})$. It quantifies the energy available for crop evapotranspiration, photosynthesis, and soil heating [21]. In some conditions, it is possible to directly relate net radiation to solar radiation by means of empirical relationships (see for example [4, 16, 19, 22]). These relationships may be difficult to extrapolate to other conditions and it is preferable to use direct measurements from automated network station when possible or estimations based on less empirical formulas.
Net radiation, $\mathrm{Rn}\left(\mathrm{W} \cdot \mathrm{m}^{-2}\right)$, may be decomposed as follow:

$$
\mathrm{Rn}=(1-\alpha) \operatorname{Rg}+\varepsilon_{\mathrm{cv}} \mathrm{Ra}-\mathrm{Rt}
$$

with a the surface albedo, $\mathrm{Rg}$ the solar global radiation $\left(\mathrm{W} \cdot \mathrm{m}^{-2}\right), \varepsilon_{\mathrm{cv}}$ the crop absorption coefficient for thermal radiation, $\mathrm{Ra}$ the atmospheric radiation which is emitted by air molecules $\left(\mathrm{W} \cdot \mathrm{m}^{-2}\right)$, and $\mathrm{Rt}$ the terrestrial radiation which is emitted by the crop canopy $\left(\mathrm{W} \cdot \mathrm{m}^{-2}\right)$. These two last terms, as well as the albedo, are not measured in classical meteorological stations. Moreover, $\alpha, \varepsilon_{\mathrm{cv}}$, and Rt depend on the type of surface and its water status. The radiative balance in the solar domain, $(1-\alpha) \mathrm{Rg}$, is the principal component of equation (1) during daytime with a representative albedo value between 0.20 and 0.25 for crops. The radiation balance in the thermal domain $\left(\varepsilon_{\mathrm{cv}} \mathrm{Ra}-\mathrm{Rt}\right)$ has usually a lower value but is the only component of the net radiation at night. The crop absorption coefficient for thermal radiation which may be considered as equal to the crop emissivity, has a almost constant value (in practical work a value of 0.98 may be taken for crop canopies). Ra and Rt can be expressed in function of air temperature and crop temperature, respectively, using the StefanBoltzman equation [21]. Then, equation (1) can be rewritten as:

$$
\mathrm{Rn}=(1-\alpha) \operatorname{Rg}+\varepsilon_{\mathrm{cv}}\left(\varepsilon_{\mathrm{a}} \sigma \mathrm{T}_{\mathrm{a}}^{4}-\sigma \mathrm{T}_{\mathrm{cv}}^{4}\right)
$$

with $\varepsilon_{\mathrm{a}}$ the emissivity of the atmosphere, $\mathrm{T}_{\mathrm{a}}$ the air temperature $(\mathrm{K}), \mathrm{T}_{\mathrm{cv}}$ the crop temperature $(\mathrm{K})$, and the Stefan-Boltzman constant $(5.67 \times$ $\left.10^{-8} \mathrm{~W} \cdot \mathrm{m}^{-2} \cdot \mathrm{K}^{-4}\right)$.

The atmospheric emissivity is a lot more variable than the crop emissivity. It depends on the atmospheric profiles of humidity and temperature. Since such information is generally not available at sites where longwave radiation is needed for particular application, many authors have proposed empirical relationships which relate the atmospheric emissivity to the air humidity or the air temperature measured in classical meteorological station $[5,7,14,26]$. These equations were applied with success at large time scales (day, decade, month) because a correlation exists between the temperature and the humidity of the air at these time 
scales. However, their coefficients were usually site dependent. It was also assumed that their results at an hourly time scale were not good and that formulations more physically sound and based on both the air temperature and the air humidity, such as those proposed by Brutsaert [8] and Idso [13], were preferable:

$$
\begin{gathered}
\varepsilon_{\mathrm{a}}=1.24\left(\mathrm{e}_{\mathrm{a}} / \mathrm{T}_{\mathrm{a}}\right)^{1 / 7}[8] \\
\varepsilon_{\mathrm{a}}=0.179 \mathrm{e}_{\mathrm{a}}^{1 / 7} \exp \left(350 / \mathrm{T}_{\mathrm{a}}\right)[13] .
\end{gathered}
$$

Idso [13] also proposed another formula with a linear dependence to the air vapour pressure:

$\varepsilon_{\mathrm{a}}=0.70+5.9510^{-5} \mathrm{e}_{\mathrm{a}} \exp \left(1500 / \mathrm{T}_{\mathrm{a}}\right)[13]$

with $\mathrm{e}_{\mathrm{a}}$ the air vapour pressure $(\mathrm{hPa})$. The two first formulas present relatively similar shapes, at least concerning the response to vapour pressure. The formula by Idso usually leads to higher value of $\varepsilon_{\mathrm{a}}$ than Brutsaert's in a normal temperature range (let say between 270 to $310 \mathrm{~K}$ ). Actually both equations are equivalent for an air temperature of $314 \mathrm{~K}$. Brutsaert [5] pointed out that his formulation was not very sensitive to $\mathrm{T}_{\mathrm{a}}$ and that a simpler expression not taking account of air temperature should give quite similar results. This was confirmed by Mermier and Seguin [20] and Idso [14]. Brutsaert also pointed out that the coefficient 1.24 in his equation, which was derived on an atmospheric radiative transfer basis, should vary according to variations in the type of atmosphere. Main differences occured because of the higher temperature sensitivity of Idso's formula which might be considered as more general and should have a better behaviour at an hourly time step. The second Idso's formula gave slightly better results on Idso's dataset. However, results obtained by Hatfield et al. [12] or Olioso [22] showed that these three formulas give very similar results with errors lower than $5 \%$ (or residual standard deviation lower than $20 \mathrm{~W} \cdot \mathrm{m}^{-2}$ ). It was also noticed in both studies that the original coefficient in Brutsaert formula (1.24) led to an underestimation of $5 \%$ in calculated atmospheric radiation. Culf and Gash [9] found very similar results (for the dry season in Niger) and were able to recompute the coefficient in Brutsaert's equation from atmospheric vapour density and temperature profiles obtained by radiosoundings. Their computed value was 1.31 .

\section{Materials and methods}

\subsection{Proposed model}

We want to derive a net radiation model that can be used at an hourly time step from classical meteorological measurements in "reference" conditions for the calculation of crop water requirements (using the Penman-Monteith equation). This model is derived from equation 2 with the following assumptions:

- albedo value is 0.25 ;

- crop emissivity value is 0.98 ;

$-T_{c v}$, the crop temperature, is equal to the air temperature $\mathrm{T}_{\mathrm{a}}$; indeed, $\mathrm{T}_{\mathrm{cv}}$ is not measured in classical meteorological networks and in the "reference" conditions defined for irrigation purposes the crop temperature is usually close to the air temperature;

- atmospheric radiation is computed from air temperature and vapour pressure using Brutsaert's formula with a modified coefficient taking account of the $5 \%$ underestimation shown by different authors (see previous section); this choice was done after a reanalysis of the data given in Olioso [22]; in Table I we show that the three formulas given by equations (3) and Brutsaert's equation with a modified coefficient give quite similar results; however Brutsaert's formula with the 1.24 coefficient and the second Idso formula presented a small bias. Then, we choose the Brutsaert's formula because the possibility of modifying its coefficient is more physically sound than for Idso's formulas (see Culf and Gash [9]).

Considering the above assumptions, the resulting model for computing $\mathrm{Rn}$ is given by equation (4)

$\mathrm{Rn}=0.75 \mathrm{Rg}+0.98\left(1.31\left(\mathrm{e}_{\mathrm{a}} / \mathrm{T}_{\mathrm{a}}\right)^{1 / 7}-1\right) \cdot \sigma \mathrm{T}_{\mathrm{a}}^{4}$. 
Table I. Test of different formulas to compute the atmospheric radiation from air temperature and vapour pressure. The data were acquired in Carpentras (South-East of France, $25 \mathrm{~km}$ North-East of Avignon) from the 10th of July to the 29th of August in 1990. Atmospheric radiation was measured using an Eppley pyrgeometre. R is the correlation coefficient between the data and the formulas, RMSE the root mean square error and B the bias.

\begin{tabular}{|c|c|c|c|c|}
\hline & & $\mathrm{R}$ & $\operatorname{RMSE}\left(\mathrm{W} \cdot \mathrm{m}^{-2}\right)$ & $\operatorname{Bias}\left(\mathrm{W} \cdot \mathrm{m}^{-2}\right)$ \\
\hline Eq. 3a: coefficient 1.24 & Brutsaert [8] & 0.76 & 28 & -20 \\
\hline Eq. $3 a$ : with a modified coefficient 1,31 & Brutsaert [8] & 0.76 & 19 & 0 \\
\hline Eq. $3 b$ & Idso [13] & 0.77 & 18 & 0 \\
\hline Eq. $3 c$ & Idso [13] & 0.77 & 20 & -6 \\
\hline
\end{tabular}

The validity of this equation is evaluated in the present study using data acquired in Chile and in France.

\subsection{Experimental data}

We used the meteorological data measured at the University of Talca in Chile $\left(35^{\circ} 23^{\prime}\right.$ South and $71^{\circ} 40^{\prime}$ West; $110 \mathrm{~m}$ above the sea level) and at the Avignon INRA research center in France (43⒌ North and $4^{\circ} 51^{\prime}$ East; $24 \mathrm{~m}$ above the sea level). Both locations experience a mediterranean type of climate, but with a more pronounced dry period in Talca. Hourly measurements of global solar radiation, net radiation, air temperature and vapour pressure were performed at each location over a reference grass surface. Solar radiation was measured with a Kipp-Zonen pyranometer (CM3) in Talca and a Kipp-Zonen pyranometer (CM6) in Avignon. Net radiation was measured using a REBS-Q7 differential pyrradiometer in Talca and a Crouzet differential pyrradiometer in Avignon. Additional measurements of atmospheric radiation were performed in Avignon using an Eppley pyrgeometer (Precision Infrared Radiometer). An accuracy of $\pm 30 \mathrm{~W} \cdot \mathrm{m}^{-2}$ was determined by Mediavilla [18] for the net radiation measurements in Talca. The data were acquired in January and May 1998 in Avignon and in April and May 1998 in Talca. Separation between day and night data have been done on the basis of solar radiation higher than zero or equal to zero. Clear sky data were sorted visually by considering the shape of the solar radiation diurnal course.

\section{Results and discussion}

Examples of the diurnal variation of observed (Rno) and estimated (Rne) net radiation are given in Figure 1 (cloudless conditions) and Figure 2 (cloudy conditions). The general shape was well reproduced in both types of conditions. However, in many cases an asymmetry was noticed between the morning and the afternoon (see Fig. 1). At night, systematic underestimation occurred, which might be more pronounced before sunrise as illustrated by the situation in Talca for the 27th of April, where observed net radiation close to zero by clear sky is to be imputed to instrumental device, not provided with a ventilation system to prevent dew. In overcast conditions, discrepancies seemed to be larger than for clear skies, sometime reaching 30 to $40 \mathrm{~W} \cdot \mathrm{m}^{-2}$ (in the case of Avignon) values which are of the order or larger than errors on net radiation measurements.

Table II shows that the performances of the net radiation model over all the selected data were similar in Avignon and in Talca. A general underestimation was seen, but the RMSE value had a similar magnitude as the experimental error on $\mathrm{Rn}$ $\left(30 \mathrm{~W} \cdot \mathrm{m}^{-2}\right)$. The linear regression calculated between Rno and Rne showed that the underestimation was usually important for the low values of net radiation, specially during the night. This is also visible in Figure 3 which compare estimated radiation to measures.

Table III shows the performances of the net radiation model in different situations in Avignon. The 

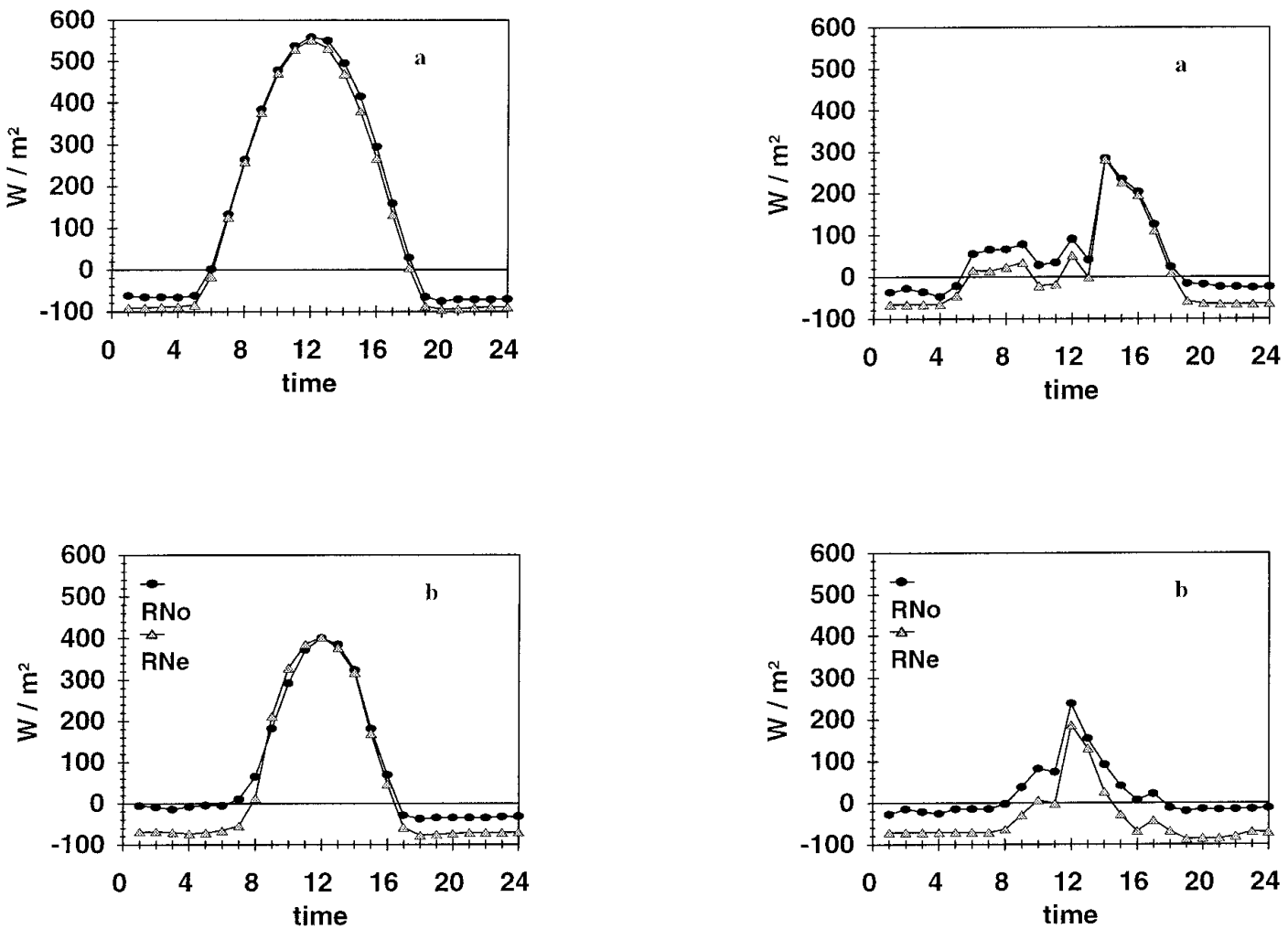

Figure 1. Observed (Rno) and estimated (Rne) net radiations in cloudless conditions in Avignon on 5/5/1998 (a) and Talca on $27 / 4 / 1998$ (b).

Figure 2. Observed (Rno) and estimated (Rne) net radiation in overcast conditions in Avignon on 28/5/1998 (a) and Talca on 8/4/1998 (b)

Table II. Statistical results of the comparison between observations and estimations of net radiation. Bias is the mean of Rne - Rno, RMSE is the root mean square error, $r^{2}$ the square of the correlation coefficient, $a$ and $b$ the coefficients of the regression Rno $=a$ Rne $+b$, and Er the standard error resulting from the regression.

\begin{tabular}{lcc}
\hline & Avignon & Talca \\
\hline $\operatorname{Bias}\left(\mathrm{W} \cdot \mathrm{m}^{-2}\right)$ & -19 & -14 \\
$\mathrm{RMSE}\left(\mathrm{W} \cdot \mathrm{m}^{-2}\right)$ & 34 & 42 \\
$\mathrm{r}^{2}$ & 0.98 & 0.97 \\
$\mathrm{a}$ & 0.910 & 0.892 \\
$\mathrm{~b}\left(\mathrm{~W} \cdot \mathrm{m}^{-2}\right)$ & 24 & 45.2 \\
$\mathrm{Er}\left(\mathrm{W} \cdot \mathrm{m}^{-2}\right)$ & 22 & 21.4 \\
Number of data & 1405 & 1395 \\
\hline
\end{tabular}

model was unbiased for daytime data and more specifically for clear sky daytime data. Large underestimation occurred for cloudy days. However, we should keep in mind that these cloudy days represented only a small part of the data set (less than $25 \%$ of the data). As noticed before, large underestimation also occurred at night. They were the principal responsible for the bias of the model on the whole data set. The comparison of observed atmospheric radiation with the calculation by means of the Brutsaert's formula showed that only very low underestimation of Ra occurred in clear sky situation during daytime and at night (Tab. IV). The good estimation of atmospheric radiation confirmed the value of 1.31 which was chosen in the formula. Large underestimation 
Table III. Statistical results of the comparison between observations and estimations of net radiation in Avignon for different atmospheric situations. Bias is the mean of Rne - Rno, RMSE is the root mean square error, $\mathrm{r}^{2}$ the square of the correlation coefficient, $a$ and $b$ the coefficients of the regression Rno $=a$ Rne $+b$, and Er the standard error resulting from the regression.

\begin{tabular}{lcccccccc}
\hline & day & Night & $\begin{array}{c}\text { cloudless } \\
\text { data }\end{array}$ & $\begin{array}{c}\text { cloudy } \\
\text { data }\end{array}$ & $\begin{array}{c}\text { cloudless } \\
\text { day }\end{array}$ & $\begin{array}{c}\text { cloudy } \\
\text { day }\end{array}$ & $\begin{array}{c}\text { cloudless } \\
\text { night }\end{array}$ & $\begin{array}{c}\text { cloudy } \\
\text { night }\end{array}$ \\
\hline Bias $\left(\mathrm{W} \cdot \mathrm{m}^{-2}\right)$ & -8 & -32 & -11 & -36 & -1 & -27 & -24 & -43 \\
$\mathrm{RMSE}\left(\mathrm{W} \cdot \mathrm{m}^{-2}\right)$ & 29 & 37 & 28 & 43 & 26 & 41 & 30 & 46 \\
$\mathrm{r}^{2}$ & 0.98 & 0.26 & 0.99 & 0.92 & 0.98 & 0.92 & 0.46 & 0.05 \\
$\mathrm{~A}$ & 0.92 & 1.15 & 0.93 & 0.79 & 0.93 & 0.75 & 1.29 & 0.65 \\
$\mathrm{~b}\left(\mathrm{~W} \cdot \mathrm{m}^{-2}\right)$ & 22 & 43 & 17 & 31 & 7 & 36 & 44 & 19 \\
$\mathrm{Er}\left(\mathrm{W} \cdot \mathrm{m}^{-2}\right)$ & 26 & 20 & 21 & 18 & 25 & 20 & 17 & 16 \\
Number of data & 728 & 677 & 973 & 401 & 535 & 170 & 431 & 232 \\
\hline
\end{tabular}
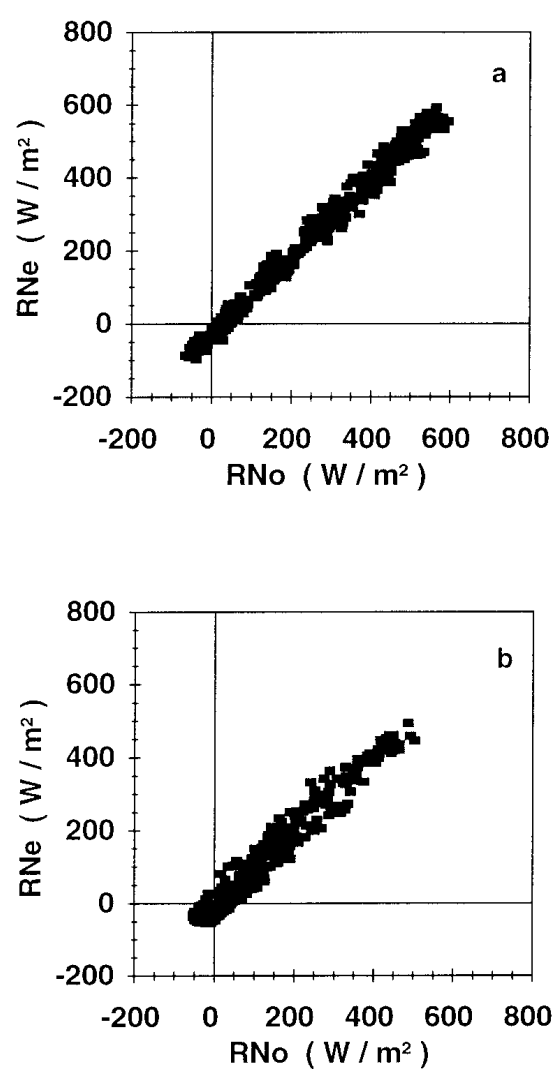

Figure 3. Comparison between the estimations (Rne) and the observations (Rno) of net radiation in all conditions in Avignon (a) and Talca (b). occurred for cloudy conditions which was not surprising since Brutsaert's formula was established only for clear skies (in cloudy conditions, the atmospheric emissivity actually increased due to the radiation emission by the clouds which is larger than the emission by atmospheric gases). The wrong estimation of atmospheric radiation maybe the main factor affecting the performance of the net radiation model in cloudy conditions. The same explanation did not hold for the underestimation of net radiation at night.

At night, a large part of the underestimation may be due to a relative lack of validity of the assumption that the surface temperature is equal to the air temperature $\left(\mathrm{T}_{\mathrm{cv}}=\mathrm{T}_{\mathrm{a}}\right)$. Actually, an analysis of night temperature for frost forecasting by Antonioletti [6] had shown that at the end of the night (time of the minimum air temperature), the temperature near the ground was lower than the air temperature by $3 \mathrm{~K}$. A simple calculation showed that if $\mathrm{T}_{\mathrm{cv}}=\mathrm{T}_{\mathrm{a}}-3, \mathrm{Rn}$ is risen by 13 to $20 \mathrm{~W} \cdot \mathrm{m}^{-2}$ (for $\mathrm{T}_{\mathrm{a}}$ varying between $0{ }^{\circ} \mathrm{C}$ and $40{ }^{\circ} \mathrm{C}$ ).

During the day, a similar problem may occur when the surface temperature depart from the air temperature generating some overestimation of the radiation balance in the thermal domain. This might be the reason of the asymmetric behaviour noticed in Figure 1 since air temperature and surface temperature have not usually the same evolution during the day: the surface temperature 
Table IV. Statistical results of the comparison between observations Rao and estimations Rae of atmospheric radiation in Avignon for different atmospheric situations. Bias is the mean of Rao - Rae, RMSE is the root mean square error, $r^{2}$ the square of the correlation coefficient.

\begin{tabular}{lcccc}
\hline & day & night & $\begin{array}{c}\text { cloudless } \\
\text { day }\end{array}$ & $\begin{array}{c}\text { cloudy } \\
\text { day }\end{array}$ \\
\hline Bias $\left(\mathrm{W} \cdot \mathrm{m}^{-2}\right)$ & -9 & -2 & -4 & -31 \\
$\mathrm{RMSE}\left(\mathrm{W} \cdot \mathrm{m}^{-2}\right)$ & 22 & 19 & 17 & 36 \\
$\mathrm{r}^{2}$ & 0.49 & 0.47 & 0.30 & 0.11 \\
Number of data & 211 & 149 & 175 & 15 \\
\hline
\end{tabular}

reaches its maximum value around solar noon, while the maximum of air temperature occurred later in the afternoon, and the difference $\mathrm{T}_{\mathrm{cv}}-\mathrm{T}_{\mathrm{a}}$ is usually lower in the afternoon than in the morning [17]. However, in diurnal conditions the radiation balance in the solar domain has also a great importance. The model consider a constant value of the albedo, while the albedo may vary with a large number of factors [10]: spectral composition of incident radiation, which depends on the amount and the type of clouds, the solar zenith angle, which depends on the time of the day and the time in the year, the fraction of solar diffuse radiation, the amount and the orientation of leaves, and the albedo of the background which may change with surface soil moisture. If albedo is lower than 0.25 the model underestimates the radiation balance in the solar domain. Samie [25] showed that the albedo of a grass canopy, similar to the one used in this study, may vary from 0.25 to 0.20 . Such variation may lead to an underestimation of net radiation of $20 \mathrm{~W} \cdot \mathrm{m}^{-2}$ if $\mathrm{Rg}=500 \mathrm{~W} \cdot \mathrm{m}^{-2}$. A compensation may occur between the effect of the temperature difference and an overestimated albedo. Measurements of surface temperature and albedo are needed to check this hypothesis.

\section{Conclusion}

We proposed a simple model for estimating net radiation at an hourly time step over "reference" conditions. The model (Eq. (4)) performed well on two data set, in Avignon and in Talca. Differences in model performance were noticed depending on the atmospheric conditions (presence of cloud and night time) and a part of nocturnal errors can be imputed to instrumental accuracy, but the global treatment of the data was satisfactory (Tab. II). Actually, as the model was tested in Mediterranean climate conditions, the data set did not include a large amount of data in cloudy condition which might diminish model performances. In other climate situation it may be necessary to include a better treatment of the effect of clouds on net radiation. It is also important to notice that the model performed very well in diurnal situation, which are the more important to consider in the estimation of evapotranspiration. The model is adapted for an easy transfer to other types of surface such as crop canopies. This will only require a modification of the albedo value. It is also interesting to notice that the $\mathrm{T}_{\mathrm{cv}}=\mathrm{T}_{\mathrm{a}}$ hypothesis has more chance to be valid for canopy taller than the reference grass because of the effect of higher aerodynamic roughness.

Our results also showed that it was possible to estimate incident atmospheric radiation by means of the Brutsaert's equation but using a modified coefficient to correct the underestimation usually noticed when using the classically employed value.

\section{References}

[1] Allen R.G., Jensen M.E., Wright J.L., Burman R.D., Operational Estimates of Reference Evapotranspiration, Agron. J. 81 (1989) 650-662.

[2] Allen R.G., Smith M., Perrier A., Pereira L., An update for the definition of reference evapotranspiration, ICID Bull. 43 (1994) 1-34.

[3] Allen R.G., Pereira L.S., Raes D., Smith M., Crop evapotranspiration. Guidelines for computing crop water requirements, FAO Irrigation and Drainage Paper 56, Roma, FAO, 1998, 300 p.

[4] André R.G.B., Viswanadham Y., Radiation balance of soybeans grown in Brazil, Agric. Meteorol. 30 (1983) 157-173. 
[5] Angström A., A study of the radiation of the atmosphere, Smithson. Inst. Misc. Coll. 65 (1918) $159-161$

[6] Antonioletti R., Délimitation des zones à risques de gel à l'aide de thermographies infrarouges satellitaires, in: Douguedroit A. (Ed.), Association Internationale de Climatologie, Colloque d'Aix en Provence, 1988, pp. 41-46.

[7] Brunt D., Notes on radiation in the atmosphere, Q. J. R. Meteorol. Res. 58 (1932) 389-418.

[8] Brutsaert W., On a derivable formula for longwave radiation from clear skies, Water Resour. Res. 11 (1975) 742-744.

[9] Culf A.D., Gash J.H.C., Longwave radiation from clear skies in Niger: a comparison of observations with simple formulas, J. Appl. Meteorol. 32 (1993) 539-547.

[10] Dickinson R.E., Land surface processes and climate - Surface albedos and energy balance, Adv. Geophys. 25 (1983) 305-353.

[11] Doorenbos J., Pruitt W.O., Crop evapotranspiration. guidelines for computing crop water requirements, FAO Irrigation and Drainage Paper 24, Roma, 1977, $156 \mathrm{p}$.

[12] Hatfield J.L., Reginato R.J., Idso S.B., Comparison of long-wave radiation calculation methods over the United States, Water Resour. Res. 19 (1983) $285-288$

[13] Idso S.B., A set of equations for full spectrum and 8 to $14 \mu \mathrm{m}$ and 10.5 to $12.5 \mu \mathrm{m}$ thermal radiation from cloudless skies, Water Resour. Res. 17 (1981) 295-304.

[14] Idso S.B., Jackson R.D., Thermal radiation from the atmosphere, J. Geophys. Res. 74 (1969) 5397-5403.

[15] Jensen M.E., Burman R.D., Allen. R.G., Evapotranspiration and irrigation water requirements, ASCE-Manuals and Reports on Engineering Practice, No 70, Am. Soc. Civil Engrs., New York, 1990, 360 p.

[16] Kowalik P.J., Turner N.C., Diurnal changes in the water relations and transpiration of a soybean crop simulated during the development of water deficit, Irrig. Sci. 4 (1983) 225-238.

[17] Lagouarde J.P., Olioso A., Interest of mid-morning acquisition of surface temperature for deriving surface fluxes, Remote Sens. Rev. 12 (1995) 287-309.

[18] Mediavilla W., Estimación de la variación diurna de la radiación global, neta y calor para la determinación de la evapotranspiración por Penman-Monteith, Tesis de Grado para Optar al Título de Ingr. Agrónomo, Esc. de Agronomía, Universidad de Talca, Chile, 1996, $66 \mathrm{p}$.

[19] Mermier M., Seguin B., Le rayonnement net à Avignon-Montfavet, INRA, Station de Bioclimatologie d'Avignon, Note M/76/4, 1976a, 14 p.

[20] Mermier M., Seguin B., Comment on 'On a derivable formula for long-wave radiation from clear skies' by W. Brutsaert, Water Resour. Res. 12 (1976b) $1327-1328$.

[21] Monteith J.L., Unsworth M.H., Principles of Environmental Physics, Edward Arnold, London, 1990, $291 \mathrm{p}$.

[22] Olioso A., Simulation des échanges d'énergie et de masse d'un couvert végétal dans le but de relier la transpiration et la photosynthèse aux mesures de réflectance et de température de surface, Doctorate thesis, Université de Montpellier, France, 1992, 250 p.

[23] Ortega-Farias S., Cuenca R., Ek M., Daytime variation of sensible heat flux estimated by the bulk aerodynamic method over a grass canopy, Agric. For. Meteorol. 81 (1996) 131-143.

[24] Ortega-Farias S., Cuenca R.H., Solis B., Ortiz C., Evaluación de calor latente usando la ecuación de Penman-Monteith, con un valor variable de la resistencia du couvert végétal a la transferencia de vapor de agua, Cienc. Invest. Agrar. 23 (1996) 61-66.

[25] Samie C., Variabilité de l'albédo d'un couvert de fétuque, Note technique STEFCE, Montfavet, France, 73/3, 1973.

[26] Swinbank W.C., Longwave radiation from clear skies, Q. J. R. Meteorol. Res. 89 (1963) 339-348. 